Nyirady, Kenneth. "Libel or Not? The War of Words between Lajos Kossuth and New York Editor, James Watson Webb." Hungarian Cultural Studies. e-Journal of the American Hungarian Educators Association, Volume 11

\title{
Libel or Not? The War of Words between Lajos Kossuth and New York Editor, James Watson Webb
}

\section{Kenneth Nyirady}

\begin{abstract}
Although three notable American editors opposed Lajos Kossuth before and during his visit to the United States in 1851-52, the most influential was arguably James Watson Webb, editor of the New York Courier and Enquirer (NYCE). Webb had been appointed by President Zachary Taylor to be Charge d'Affaires to Vienna in 1849 but had neglected to wait for confirmation by the Senate before traveling to Vienna. When the Senate rejected his appointment by an overwhelming vote, an embittered Webb was obliged to return to the United States. Although Webb had made many political enemies, the public reason given for his Senate rejection was that body intended to keep the post vacant as a "punishment" for Austria's brutal suppression of the Hungarian rebels after their defeat in August 1849. Webb allegedly held Kossuth responsible for his rejected nomination, and upon returning to the United States and resuming the day-to-day operations of the NYCE, the paper's coverage of Hungary and Kossuth turned negative. During his visit to New York, Kossuth hinted that the Austrians might have bribed a certain New York editor to publish falsehoods about the Hungarian War of Independence. Webb took this hint as a personal attack and demanded an explanation from Kossuth, who never clearly explained which editor he was referring to.
\end{abstract}

Keywords: Lajos Kossuth, James Watson Webb, New York Courier \& Enquirer, New York Times, journalism

Biography: Kenneth Nyirady is Head of the European Reading Room, Library of Congress, and has served as the specialist for Hungary and the Finno-Ugrian areas of Russia in the Library's European Division since 1990. He received an M.A. in Russian History from Binghamton University in 1976 and an M.Phil. in Uralic Studies from Columbia University in 1979. kenyirady@verizon.net

Lajos Kossuth was generally met by enthusiasm during his 1851-52 United States visit, but there were notable individuals and groups who opposed him and his mission. They included the abolitionists (who thought he was shamelessly avoiding the slavery question), most Southern politicians (who thought he was in league with the abolitionists), the well-moneyed (who did not want business disrupted by European wars), the isolationists (who did not want the US meddling in foreign politics) and the hierarchy and general membership of the Catholic Church in the US (because Kossuth opposed the Catholic Habsburgs and admired the English, who oppressed the Catholic Irish). Several editors of influential publications were among Kossuth's opponents, such as Francis Bowen, editor of the North American Review (primarily a literary journal) and Orestes 
Nyirady, Kenneth. "Libel or Not? The War of Words between Lajos Kossuth and New York Editor, James Watson Webb." Hungarian Cultural Studies. e-Journal of the American Hungarian Educators Association, Volume 11 (2018) DOI: 10.5195/ahea.2018.317

Brownson, editor of Brownson's Quarterly Review, a publication covering a variety of topics from a decidedly Catholic viewpoint.

If circulation and frequency of publication are taken into account, the most influential editor that opposed Kossuth was James Watson Webb of the New York Courier and Enquirer (henceforth referred to as the Courier or NYCE), a large (in more ways than one) commercial newspaper whose readership far exceeded that of Bowen's and Brownson's journals. It was also a daily newspaper as opposed to a journal published monthly or quarterly. Unlike the two journals mentioned above which were published in Boston, the Courier was published in New York City, the commercial capital of the United States. Although devoted primarily to business, the Courier covered events abroad and also supported a network of correspondents in Washington and Europe (Crouthamel 1969: 55). The physical size of the Courier was expanded to eleven columns per page in 1850, making it physically larger than even the London Times. According to its own estimation, it was the "largest folio daily journal published in the world" (NYCE 1851/01/28).

We must remember that before the age of radio and television, and well before the current age of instant communications, newspapers were the main medium of mass communication and exerted enormous influence over public opinion. It was not without reason that the Habsburgs feared Lajos Kossuth, editor of Országgyülési tudósitások ['Parliamentary Reports'], and threw him in prison for publishing the paper. When released, Habsburg officials thought they could control Kossuth by letting him establish Pesti Hirlap ['Pest News'] with a police informer as the printer (Deak 1979: 35). But as they later found out, nobody could control Lajos Kossuth.

Beginning in the 1830s, the influence of newspaper editors in the United States increased even further. The advent of the "penny paper" meant that the average person could afford to buy (and read) a newspaper, paying one cent per issue, instead of having to pay dollars up front for a yearly subscription. At the same time, printing press technology developed-hand presses were replaced by steam presses and flat presses by cylinder presses - thus greatly increasing output and helping publishers meet the increased demand for current information. News reporting became more timely as editors sought new ways of obtaining news quickly, progressing from pony express to railroads to telegraphs, then from sail to steam for ships coming from Europe and other parts of the world. Add to this the pooling of reporting resources (eventually giving rise to the Associated Press), and the end result led to getting more current news into the hands of more readers (Emery 2000: 97-119).

Webb joined the Morning Courier in 1827 and became editor when it merged with the New York Enquirer in 1829. By 1832, the Courier and Enquirer had become the largest daily in the world, both in physical size and circulation. Its coverage of foreign affairs was greater than that of its competitors, as Webb had developed a network of foreign correspondents (Crouthamel 1969: 55, 83). 
Nyirady, Kenneth. "Libel or Not? The War of Words between Lajos Kossuth and New York Editor, James Watson Webb." Hungarian Cultural Studies. e-Journal of the American Hungarian Educators Association, Volume 11

In late 1849, President Zachary Taylor nominated Webb to be U.S. Chargé d'affaires in Vienna. ${ }^{1}$ Webb was disappointed that he had not been appointed to a post with more prestige but expected to be named to one as soon as such a position opened. He proceeded to Vienna but a bit prematurely, as he did not wait to be confirmed by the Senate. He left the United States before his confirmation not out of presumption but to escape bill collectors and an irate father-in-law. Webb, close to fifty, had just married a woman half his age, and the bride's father was not thrilled about his new son-in-law, however illustrious he might be (Crouthamel 1969: 112; Congressional Globe 31:1:103).

Webb found himself in Vienna without credentials in December 1849, only months after Austria and Russia's suppression of the Hungarian War of Independence and the repression that followed, including the execution of the thirteen generals at Arad. Meanwhile, the Senate responded to popular outrage about the events in Hungary and debated whether to break diplomatic relations with Austria or not as a sign of protest. Because of this public outrage against Austria, and because Webb had made many political enemies in Washington, the Senate voted against his confirmation (34-7), and the embittered editor returned to the states. One scholar suggested that Webb held Kossuth responsible for his misfortune (Crouthamel 1969: 123). Incidentally, diplomatic relations between the United States and Austria, however unsettled they had become at that moment (and would become in the next few years), were never severed.

While Webb was in Europe, the managing editor of the Courier was Henry Raymond, who later found the New York Daily Times (NYDT; later called the New York Times). Raymond had joined the Courier in 1843 and according to Webb's biographer, he "improved the scope and tone of the newspaper, broadened its cultural horizons, and provided a needed restraint to Webb's impetuousness..." (Crouthamel 1969: 87). To describe Webb as impetuous is an understatement, as he did not shrink from physical fights or even duels. He considered himself the "most abused personage" in American journalism but brought this abuse on himself. In this respect Webb was not unique among New York City editors, who have been called "a boisterous, crude, outspoken, brawling group," for whom "[b]rawn counted for nearly as much as intellect" (Crouthamel 1969: $15)$.

Webb returned to the United States in October 1850 but appears not to have resumed the day-to-day editorship of the Courier. The paper continued to publish articles sympathetic to the Hungarians, as it had for the time he was in Europe. For example, an editorial in November 1850 called for the United States government to work with the Ottoman Sultan, who offered to transport the exiled Hungarians detained in Turkey to Liverpool if the Americans would in turn convey them across the Atlantic. It praised Kossuth as "no wily conspirator nor turbulant [sic] demagogue, but a great, and earnest and a true man whose lofty soul makes him worthy to stand by the side of our own WASHINGTON" (NYCE 1850:11/28).

1 The United States government did not accredit ambassadors until 1893. Before that time, the title of Minister was the highest rank in the foreign service. Below that was the rank of Chargé d'affaires, who was accredited only to the host country's foreign ministry. Webb was to succeed William Henry Stiles, whom Kossuth's government approached to help arrange an armistice between the Hungarian and Habsburg forces, and who later wrote the magisterial work Austria in 1848-49 (New York: Harper \& Brothers, 1852). 
Nyirady, Kenneth. "Libel or Not? The War of Words between Lajos Kossuth and New York Editor, James Watson Webb." Hungarian Cultural Studies. e-Journal of the American Hungarian Educators Association, Volume 11

A January 1 article reported the administration's release of the correspondence between Secretary of State Daniel Webster and the Austrian Chargé in Washington, Johann Georg Hülsemann. Through Hülsemann the Austrian government had protested the mission of A. Dudley Mann, a special envoy whom President Zachary Taylor had sent to Europe to investigate the Hungarians' chance of achieving independence. Hülsemann's note to Webster was arrogant and condescending but it permitted Webster to craft a reply that, while reaffirming American neutrality, announced the country's sympathies for those attempting to overthrow tyranny (Webster 1987: 43-46, 49-61). The Courier article praised Webster for the style and substance of his letter and lamented what it believed to be the cowardice of Congress in voting down a motion to print an additional 10,000 copies of the correspondence (NYCE 1851: 1/01).

A January 20 article reviewing the contents of newly published journals took to task the latest issue of Brownson's Quarterly Review. While describing it as "able and interesting," the journal was said to contain "views and principles, which meet our most unqualified condemnation." Among the articles criticized was "The Hungarian Rebellion," (see further Brownson 1851a) which was called "anti-republican, and radically vicious," labeling the American press as "the most enslaved press in the world, and that its censor and master is the mob, the worst and meanest of tyrants..." (NYCE 1851:1/20). This review is notable as the Courier would be echoing Brownson's sentiments within months, not opposing them. An article later that month related the intrigue surrounding the escape of Kossuth's wife and children from Hungary and ended by quoting a sympathetic American calling for Kossuth to be brought to this country (NYCE 1851:1/28).

Then in the spring of 1851 the Courier's view of Hungary took an abrupt turn, suggesting that Webb had taken back day-to-day operations of the paper. On April 12, 1851, he published an article summarizing what he believed to be the failings of the Magyars in twenty-eight points. Webb claimed that the Magyars had extorted "nearly their entire independence" from the Emperor "in his hour of trouble;" that they had not only refused to grant the Slavs of Hungary the same independence, but asked the Austrian Emperor for help in their suppression; that Kossuth was responsible for the deaths of two high Austrian officials; that the Magyars declared full independence only after the Austrian Emperor issued a new constitution granting greater freedom to all peoples of the empire; and that the Magyars did not declare a republic upon declaring independence, but instead left open the possibility of a return to monarchy. Webb claimed that for eight centuries a small minority of Magyars had kept the Slavic majority in the country "in most servile bondage... of the same absolute character as our Negro Slavery, only much more severe," and "Kossuth and his Government warred in defence of Slavery and oppression and against personal and political rights; and that all good men and friends of liberty throughout the world, should rejoice in his overthrow..." (NYCE 1851: 4/12).

As the Courier the day before had reviewed an issue of Brownson's Quarterly Review that contained the second part of an article entitled the "Hungarian Rebellion," (see further Brownson 1851b) it is tempting to think that Webb relied on Brownson for his own article. However, the review of Brownson in the Courier merely recounted, but did not add to, Brownson's criticisms of both Kossuth and Daniel Webster. Brownson's article is said to be "able, but its argumentation is not strong enough to keep in countenance the violence of its language" (NYCE 1851: 4/11). This rather neutral view of Brownson's ideas makes the open attack on the Hungarians in the next issue somewhat perplexing, unless Webb was keeping his 
Nyirady, Kenneth. "Libel or Not? The War of Words between Lajos Kossuth and New York Editor, James Watson Webb." Hungarian Cultural Studies. e-Journal of the American Hungarian Educators Association, Volume 11 (2018) DOI: 10.5195/ahea.2018.317

passion in check for his tour de force the following day. Brownson could have provided some of the material for Webb's attacks, but Webb undoubtedly relied on articles critical of Kossuth and the Hungarian War of Independence written by Francis Bowen in the North American Review. (see further Bowen 1850-1851) Webb repeated Brownson's and Bowen's errors in relying on pre-1848 sources, thus ignoring all reforms that took place in Hungary before the war began, such as the abolition of feudal obligations and the establishment of equal rights. Among other errors, Webb also claimed that the Hungarian nobility was exclusively Magyar, and he criticized the Hungarian Declaration of Independence for not establishing a republic. But neither did the American Declaration of Independence, the New York Daily Times later pointed out (NYDT 1851: 12/03).

It is also likely that Webb's outlook was colored by his stay in Vienna and contact with well-positioned Austrian officials, as Kossuth would later suggest, but there is no way to know the extent of this influence (Webb 1851). In any event, Webb's April 12 article would serve as a focus of controversy during Kossuth's visit. Webb continued his criticism of Kossuth in the weeks leading up to Kossuth's arrival in early December 1851. This included a letter written to President Millard Fillmore in October, warning the President about making Kossuth "the nation's guest" (Webb 1851). He also attacked Kossuth in a lengthy article on November 21, which repeated what he had written back in April. He stressed that the press must fight popular prejudices, no matter how difficult it was to do so (NYCE 1851:11/21). Coming to Kossuth's defense was the New York Daily Times, edited by Webb's former associate Henry Raymond. The feud between the Courier and the Times provides an illuminating backdrop to Kossuth's stay in New York. It also helps fill in the gaps resulting from an incomplete run of paper copies of the Courier for December 1851, whereas every issue of the Times is available electronically, via Proquest.

Webb continued his attacks on Kossuth. In an article published two days before Kossuth's arrival in New York, the Courier labeled Kossuth "a Slav, fighting against his own people," who wanted to involve the United States in a "disastrous European war." "Let Kossuth be received with all the honors due to the nation's guest," Webb conceded, "[b]ut in the name of Washington himself ... let not the people forget what is due to themselves and to our nation's peace and prosperity, by listening to his appeals in behalf of an interference in European politics" (NYCE 1851: 12/03).

When Kossuth and company arrived in the United States they were held in quarantine for a day on Staten Island, just across New York Harbor from Manhattan. Kossuth gave his first major speech there, in which he said these words: "But yet after all, my humble capacity has not preserved me from calumnies... So long as despots exist in the world, and despots can find the means to pay, they will find men to calumniate those who are opposed to despotism and tyranny." Here Kossuth raised the possibility that his opponents may have been bribed by the Habsburgs. No specific accusation was made, but Webb believed the barb was aimed at him and the Courier, the only newspaper in New York City that questioned the motives and goals of those who led the Hungarian War of Independence. The Times, noting that Kossuth did not mention the Courier by name, wondered why Webb jumped to this conclusion, adding that although Webb's opinions were likely formed in Vienna, it "certainly does not imply that they were paid for..." (NYDT 1851: 12/09). 
Nyirady, Kenneth. "Libel or Not? The War of Words between Lajos Kossuth and New York Editor, James Watson Webb." Hungarian Cultural Studies. e-Journal of the American Hungarian Educators Association, Volume 11

In the meanwhile, Webb continued his attacks, but his unpopularity in doing so was demonstrated at the Municipal Banquet held in Kossuth's honor on December 11. At the end of Kossuth's speech various toasts were given, as was the custom. After a toast to the press was given, Webb, as the most senior editor of the New York City press, got up to respond, but so did Henry Raymond of the Times. Suddenly, confusion broke out in the hall, requiring police intervention. After the audience quieted down Raymond spoke first, and when Webb again attempted to address the audience he was interrupted by booing and hissing. He said a few words from a prepared speech and then sat down. Most of Webb's speech remained undelivered but was published later in the New York papers, including the Times. The Times again wondered why Webb was so sensitive to Kossuth's remark about tyrants finding advocates for pay. It wrote in Webb's defense:

The leading papers of this City are too powerful, and the men who have control of them have too much character and self-respect, to subject them for a moment to such suspicions. We do not believe there is one of them who would not resent with scorn, and as the greatest insult, any attempt to control his opinions by the use of money. And even if there were an exception, it would not be found in the person of Gen. Webb. We differ from him widely in opinion: we do not think he has shown a due degree of fairness and of regard for the facts which resist his positionbut we should resent, quite as warmly as he could, any intimation that his opinions or his advocacy had been bought - or that either could be bought for any purpose, or any cause whatever (NYDT 1851: 12/12, 1851: 12/13).

The New York press held its own banquet for Kossuth four days later. Webb did not attend on account of his rough treatment at the Municipal Banquet, so he returned his tickets ( $B S$ 1851: 12/17). In his speech at the press banquet, Kossuth complained about the "foul calumnies, falsehood and misrepresentations" that appeared in certain New York papers that absurdly claimed, Kossuth continued, "that we struggled for oppression while it was the cursed Austrian dynasty which stood forth for liberty" (NYDT 1851: 12/16).

The next day, various New York papers printed transcripts of Kossuth's speech. Apparently, Kossuth's team distributed two versions of the speech. One, which the Courier received, was distributed to all of the papers. An earlier version was published only in the New York Sun, which had the largest circulation of any paper in New York (NYCE 1851:12/23). The Sun version contained a paragraph not found in the subsequent version. In it, Kossuth wrote these words:

But one curious incident I may perhaps be permitted to state, which must be entirely new to you. I was at Kutahia, a prisoner, when, several weeks before the alluded to article appeared printed here, I got, by the kindness of some brave friends from Vienna, via Constantinople, (mark well, gentlemen - from Vienna,) a manuscript with the intimation that it was a copy of the article which would soon appear in an American newspaper, the copy taken for my use by an honest man, in the very bureaus of the Austrian Ministry. I have shown the manuscript to my associates, several of whom being here can remember and testify to the curious fact; and indeed, some weeks later, the very article appeared in an American newspaper, and it is that very compound of misrepresentations and calumny, to which I was alluding to. Now it is not mine to investigate this strange affinity between an 'independent' American journal, and the secret Cabinet of Austria; it 
Nyirady, Kenneth. "Libel or Not? The War of Words between Lajos Kossuth and New York Editor, James Watson Webb." Hungarian Cultural Studies. e-Journal of the American Hungarian Educators Association, Volume 11 (2018) DOI: 10.5195/ahea.2018.317

may be quite an innocent accident. I only mention it as a contribution to the cabinet of curiosities of the world. Let it be, it is not worthwhile to dwell upon it (NYCE 1851: 12/23).

Webb was outraged when he read this. Kossuth was not only implying collusion between Webb and the Austrian government, but also, if one looks back on Kossuth's Staten Island speech, that Webb was bribed to publish an anti-Hungarian article written for him in Vienna. Webb accordingly wrote a note to Kossuth enclosing this extract, and asked him whether the Courier \& Enquirer was the newspaper he was alluding to. Kossuth replied through his secretary, Ferenc Pulszky, that the extract was not from the speech, and that the copy of the speech sent to the Courier and Enquirer was the same copy sent to all the other newspapers. But the messenger who delivered Webb's inquiry to Kossuth reported back that Kossuth had read Webb's note in front of him, and did not deny that he had written the paragraph, but claimed it had been "suppressed." Webb's office then asked the New York Sun how it obtained its copy of Kossuth's speech, and the reply was that it came from the Times. Now the Times did not publish the offending extract; the Times published the second version of the speech. The Sun, with the largest circulation of any newspaper in New York City, published the first (NYCE 1851: 12/23).

So why was the paragraph "suppressed?" A correspondent from the Baltimore Sun surmised that Kossuth deemed it unwise to incorporate it into his speech, possibly because Webb was one of the press banquet's hosts (BS 1851: 12/17). But a transcript of the speech with the offending paragraph had already been distributed, at least to the New York Times. The New York Sun obtained its copy of the speech from the Times. A revised version was later sent out, which was what the Times published, but the New York Sun had already published the first. Kossuth claimed through Pulszky that the same copy had been sent to all papers, which was technically true, but omits the fact that an earlier copy of the speech had gone out to the Times. Webb asked his readers: What was more likely, that Kossuth had written the offending passage or the Times had made it up and inserted it into the speech (NYCE 1851:12/23)?

Concerning his original article of April 12, 1851, Webb claimed to have written it within thirty-six hours prior to its publication. The Times, which generally supported Kossuth, observed that although the article "was thoroughly in the Austrian interest" and showed a "malignant hatred of Kossuth and his cause," it concluded that Webb himself had written it, or, more precisely, plagiarized it, "extracts, blunders and all," from the North American Review. The Times claimed that "hundreds" of copies of the article were sent to Vienna, and it is very likely that a copy was sent to Kossuth, which he falsely assumed that it was to be published and not that it had already been published. "And this is probably the whole story," the Times concluded (NYDT 1851: 12/20).

As far as Webb was concerned, that was not the whole story. Webb called Kossuth's allegations "a deliberately manufactured FALSEHOOD" and the Times dishonest in its treatment of the story. He denied that he sent "hundreds" of copies to Austria or that copies of the article were mailed to the Austrian court. If that were true, why did Kossuth receive a mere "copy" instead of a published original? Webb accused Kossuth of being the first to suggest that any foreign representative of the United States government had been bribed by a foreign power. Therefore, Kossuth insulted the foreign service and the country itself. All because, Webb continued, we oppose Kossuth for attempting to make us forget Washington's advice to involve us in European wars. Webb boiled down the situation to this: "Either we have been BRIBED by 
Nyirady, Kenneth. "Libel or Not? The War of Words between Lajos Kossuth and New York Editor, James Watson Webb." Hungarian Cultural Studies. e-Journal of the American Hungarian Educators Association, Volume 11

Austria, and Kossuth is an honest, great, and honorable man, as well as an able, and eloquent one; or we have NOT been BRIBED by Austria, and Louis Kossuth is able and eloquent, but CUNNING, FALSE, and without the shadow of PRINCIPLE upon which to base a claim to the respect of the American people" (NYCE 1851: 12/23).

Two days later, in a Christmas day article, the Times continued its defense of Kossuth, insisting that Kossuth never said nor put into print the statement that Webb accused him of making, and again wondered why Webb was so sensitive about the subject. But then again, the Times noted in a dig at Webb that "a vain, weak man may be bribed by flattery as well as by money." The Times doubted that the people of the United States felt slandered as their representatives in Washington voted down Webb's confirmation "by an almost unanimous vote." The Times then returned to the speech as delivered and repeated that it did not contain the offending paragraph, and neither did the corrected proofs sent to the newspapers. In the opinion of the Times, Webb had no cause to complain (NYDT 1851: 12/25).

But the Times continued to avoid the question of why the original copy of the speech it received contained the offending paragraph in the first place. Who else but Kossuth could have written it? And if Kossuth wrote it, then Webb's reaction was justified. If he did not write it, then who did and why? Undoubtedly, Kossuth wrote it but had second thoughts about delivering it. As the Baltimore Sun correspondent had noted, he probably thought that it would be inappropriate to insult one of the hosts of the banquet. He probably also realized that it could set off a firestorm and perhaps cause him legal troubles, which could divert him from his mission in America to raise money and men for the future liberation of Hungary. Kossuth had refused to address the slavery issue in the United States for the very same reason. So, having second thoughts, he omitted the offending passage from his speech at the last minute but not before a copy of the speech had gotten out at least to the Times, which sent it on to the New York Sun. A second, revised copy was then rushed to all the major newspapers.

On the other hand, it might not have been an embarrassing error but instead a planned attack on Webb. In this fashion, Kossuth was able to cast a shadow on the credibility of a powerful opponent while denying it was an intentional attack. This could have been Kossuth the lawyer in a courtroom making a controversial statement that he knew would cause the opposing lawyer to object, and the objection sustained by the judge, who would then instruct the jury members to disregard what they had just heard. But the jury cannot "unhear" what it has heard, just as readers cannot "unread" what they have read. Undoubtedly, Kossuth could have felt justified in his actions, considering the many falsehoods and misrepresentations published by Webb about him and the Hungarian War of Independence. Kossuth may have believed that the article was written in Vienna and Webb was bribed to publish it but could not prove it, and therefore could not openly state it without legal consequences. Webb moved in governmental circles in Vienna while residing there, so it is safe to assume that Webb's attitudes about Kossuth and the Hungarians were formed there. But to jump from guilt by association to that of bribery is a huge leap. Although Kossuth merely hinted at bribery, it was therefore obvious to Webb at whom the innuendo was directed.

The controversy died down when Kossuth left New York, but not completely because Webb had the last word. In an editorial published two days after Kossuth's departure from the United States, Webb remarked on how times had changed: Kossuth had arrived to much acclaim and celebration in the previous December, but left surreptitiously under the alias Alexander 
Nyirady, Kenneth. "Libel or Not? The War of Words between Lajos Kossuth and New York Editor, James Watson Webb." Hungarian Cultural Studies. e-Journal of the American Hungarian Educators Association, Volume 11

Smith, "a pale and humble man in plain citizen's dress." Webb noted that when Kossuth arrived it was inopportune, perhaps impossible, to oppose him and his plans for intervention, pointing to himself as an example: "By Kossuth himself and by his most zealous adherents we were denounced and anathematised. Calumnies, which if true ought to have sunk us from the sight of man forever, were hurled at us without stint or scruple." But times had changed and Webb observed with great satisfaction that no one now was suggesting that Washington's warning against involvement in European wars should be ignored. Webb predicted that the Kossuth "excitement" will be considered as "one of the strangest of historical enigmas." He then repeated his view that the Hungarian war was one of races and not for liberty; that Kossuth's associates deemed him "untrustworthy;" that intervention against Russia four thousand miles away and on Russia's own borders was a military impossibility for the United States; that Kossuth had no right to be called "Governor;" that he was brought from Turkey under the pretense that he would retire quietly in the United States; that he attempted to drive a wedge between the people of the United States and its government; and, finally, that he had no authority to issue Hungarian bonds, knowing that they might not be repaid (NYCE 1852: 7/16).

Almost as footnote to the Webb-Kossuth affair was a scandal involving Kossuth that Webb claimed to have uncovered right after Kossuth left for Europe. Webb somehow obtained instructions written by Kossuth to an agent regarding plans to establishing a military colony in the Dominican Republic to serve as a base for the future liberation of Hungary. These plans were found in Kossuth's hotel room, allegedly left behind in Kossuth's haste to leave. To discuss and analyze those plans would require a separate study, but it is enough to say here that such military activity by private citizens was illegal at that time according to United States law. Webb forwarded the memorandum to Secretary of State Daniel Webster, along with a note vouching for the veracity of the document (Webb 1852). It seems strange that Kossuth would carelessly leave such a sensitive memorandum behind in his hotel room. One scholar suggests that Webb may have had a hotel employee steal the document (Komlos 1973: 125). If so, it would not have been out of character for Webb or, for that matter, the rough and tumble world of the New York City press in the $1850 \mathrm{~s}$.

\section{Works Cited}

Bowen, Francis. 1850. "The War of Races in Hungary.” North American Review 70, no. 147, March 1850: 473-520

. 1851. "The Rebellion of the Slavonic, Wallachian and German Hungarians against the Magyars." North American Review, vol. 150, no. 72, January 1851, $205-249$.

Brownson, Orestes. 1851a. "The Hungarian Rebellion.” [Part 1] Brownson's Quarterly Review 5 (New Series), no. 1, January 1851, 30-67. . 1851b. "The Hungarian Rebellion." [Part 2] Brownson's Quarterly Review 5, New

Series, no. 2, April 1851, 164-197.

$B S$. Baltimore Sun 1851. ProQuest Historical Newspapers, https://search.proquest.com/hnpbaltimoresun

Congressional Globe 1850. United States, Congress. Congressional Globe, 31 st Congress, $1^{\text {st }}$ Session. 
Crouthamel, James L. 1969. James Watson Webb; a Biography. Middletown, CT: Wesleyan UP.

Emery, Michael C., Edwin Emery, and Nancy L. Roberts. 2000. The Press and America: An Interpretive History of the Mass Media. 9th ed. Boston: Allyn \& Bacon.

Komlos, John H. 1973. Louis Kossuth in America, 1851-1852. Buffalo, NY: East European Institute.

NYCE. 1850-1852. New York Courier and Enquirer. (See citations for article dates.)

NYDT. 1851. New York Daily Times. ProQuest Historical Newspapers, https://search.proquest.com/hnpnewyorktimes. (See citations for article dates.)

Webster, Daniel. 1987. "Daniel Webster and Europe. Hulsemann, Amin Bey, and Louis Kossuth." In The Papers of Daniel Webster. Diplomatic Papers, vol. 2. Ed. Kenneth Shewmaker and Kenneth R. Stevens. Hanover, NH: UP of New England.

Webb, James Watson. 1851. "Letter of James Watson Webb to Millard Fillmore, October 17, 1851." In Millard Fillmore Papers, Library of Congress. . 1852. "J. W. Webb to Daniel Webster." Massachusetts Historical Society. Proceedings 44, October 1910 - June 1911, 212-213. 